\title{
HUBUNGAN ASUPAN ZAT GIZI MAKRO DAN ZAT GIZI MIKRO DENGAN STUNTING PADA ANAK USIA 24-59 BULAN DI WILAYAH KERJA PUSKESMAS KABERE KECAMATAN CENDANA KABUPATEN ENREKANG
}

\section{RELATIONSHIP OF MACRO AND MICRO NUTRITION INTAKE WITH STUNTING IN CHILDREN 24-59 MONTHS IN PUSKESMAS KABERE KECAMATAN CENDANA ENREKANG REGENCY}

\author{
Nur Amaliah Ramadhani Nur ${ }^{1}$, Burhanuddin Bahar ${ }^{1}$, Djunaidi M. Dachlan ${ }^{1}$ \\ (Email/Hp: nuramaliahramadhaninur@yahoo.com/085656362693)
}

${ }^{1}$ Program Studi Ilmu Gizi, Fakultas Kesehatan Masyarakat,Universitas Hasanuddin, Makassar

\begin{abstract}
ABSTRAK
Pendahuluan: Stunting merupakan salah satu masalah gizi yang muncul sebagai salah satu masalah kesehatan di Indonesia. Global Nutrition Report tahun 2014 menunjukkan Indonesia termaksuk dalam 17 negara, di antara 117 negara, yang mempunyai tiga masalah gizi yaitu stunting, wasting dan overweight pada anak. Berdasarkan Hasil Riset Kesehatan Dasar pada tahun 2018 Sulawesi Selatan berada pada peringkat ke 6 provensi dengan prevalensi tinggi dengan presentase 35\%. Tujuan: Penelitian ini bertujuan untuk mengetahui hubungan asupan zat gizi makro dan mikro pada anak usia 24-59 bulan di wilayah kerja Puskesmas Kabere Kabupaten Enrekang. Metode: Jenis penelitian yang digunakan adalah deskriptif analitik dengan rancangan cross sectional. Sampel penelitian ini adalah balita usia 24-59 bulan. Didapatkan sebanyak 105 sampel. Teknik sampling dalam penelitian ini adalah cara probability sampling menggunakan teknik purposive sampling. Asupan zat gizi makro dan mikro di ukur dengan cara wawancara langsung kepada orang tua. Hasil: Hasil penelitian ini didapatkan bahwa balita 24-59 bulan diwilayah kerja Puskesmas Kabere Kecamatan Cendana Kabupaten Enrekang yang mengalami stunting sebanyak 46,7\% dan yang normal sebanyak 53,3\%. Dalam penelitian ini, didapatkan hasil berdasarkan uji statistik Chi-Square bahwa terdapat hubungan yang sgnifikan antara asupan zat gizi makro (Karbohidrat, Protein, Lemak) $(\mathrm{p}<0,005)$ dengan stunting, terdapat hubungan yang signifikan antara asupan zat besi dan zink ( $\mathrm{p}<0.005)$, Namun, tidak terdapat hubungan yang signifikan antara asupan kalsium dengan vitamin D dengan stunting $(\mathrm{p}>0.005)$. Kesimpulan: Terdapat hubungan signifikan antara asupan zat gizi makro serta zat besi dan zink dengan stunting.
\end{abstract}

\section{Kata kunci : Stunting, Zat Gizi Makro, Zat Gizi Mikro}

\section{ABSTRACT}

Introduction: Stunting is one of the nutritional problems that appears as one of the health problems in Indonesia. The 2014 Global Nutrition Report shows that Indonesia is included in 17 countries, among 117 countries, which have three nutritional problems, namely stunting, wasting and overweight in children. Based on the results of Basic Health Research in 2018 
South Sulawesi was ranked 6th in the prevalence of high prevalence with a percentage of 35\%. Aims: The purpose of this study was to determine the relationship between macro and micro nutrient intake in children aged 24-59 months in the working area of Kabere District of Enrekang. Materials and Methods: The type of research used is descriptive analytic with cross sectional design. The sample of this study was toddlers aged 24-59 months. 105 samples were obtained. The sampling technique in this study is the method of probability sampling using purposive sampling technique. Intake of macro and micro nutrients is measured by interviewing parents directly. Results: The results of this study found that toddlers 24-59 months in the work area of the Kabere Health Center in the District of Cendana, Enrekang District, were stunting at $46.7 \%$ and the normal ones were $53.3 \%$. In this study, the results obtained based on Chi-Square statistical tests that there is a significant relationship between macro nutrient intake (Carbohydrate, Protein, Fat) ( $p<0.005)$ with stunting, there is a significant relationship between iron intake and zinc $(p<0.005)$, however, there is no significant relationship between calcium intake and vitamin $D$ by stunting ( $p>0.005$ ) Conclussion: There is a significant relationship between macronutrient intake and iron and zinc intake.

\section{Keywords : Stunting, Macro Nutrition, Micro Nutrition}

\section{PENDAHULUAN}

Masalah gizi merupakan suatu persoalan yang dianggap menjadi masalah utama dalam pembangunan disuatu negara. Persoalan tersebut menjadi salah satu poin penting yang menjadi bagian dari Sustainable Development Goals (SDGs). ${ }^{1}$ Gangguan pertumbuhan terjadi pada usia anak-anak, khususnya umur dibawa 5 tahun dapat meningkatkan risiko penyakit kronis, salah satu gangguan pertumbuhan pada masa tersebut adalah stunting. ${ }^{2}$ Stunting adalah retardasi pertumbuhan linear defisit panjang badan kurang dari-2 standar deviasi indikator panjang badan menurut umur. ${ }^{3}$ Stunting juga didefinisikan sebagai tinggi badan yang relative rendah di bandingkan anak usia dan jenis kelamin yang sama yang tumbuh dibawah kondisi yang tidak membatasi pertumbuhan. Pertumbuhan linear pada anak usia dini dianggap sebagai penanda pertumbuhan yang sehat. ${ }^{4}$

Berdasarkan hasil Riset Kesehatan Dasar (RISKESDAS) pada tahun 2018 prevalensi pendek (stunting) sebesar 29.9\% Prevalensi pendek sebesar 19,3\% dan sangat pendek $11,5 \%$ persen pendek, yang berarti terjadi menurunan angka stunting dibandingkan tahun 2013 sebesar (37,2\%), akan tetapi prevalensi tersebut masih di atas ambang batas yang telah di tetapkan oleh WHO (20\%). Sulawesi Selatan berada pada peringkat ke 6 provinsi dengan prevalensi tinggi dengan persentase $35 \%{ }^{3}$ Berdasarkan data Seksi Gizi Masyarakat Tahun 2015 dalam Laporan Dinas Kesehatan Provensi Sulawesi Selatan Tahun 2015 prevalensi stunting di Kabupaten Enerekang mencapai 39.6\% atau ditemukan sebanyak 118 kasus. Laporan Penilaian Satus Gizi (PSG) Dinas Kesehatan Enrekang melapor bahwa prevalensi stunitng di kecamatan Cendana Kabupaten Enrekang mencapai 25\% dari jumlah sasaran yaitu sekitar 196 balita dari jumlah sasaran 776 balita. $^{3}$

Berdasarkan uraian diatas, peneliti tertarik untuk mengetahui lebih lanjut untuk mengetahui lebih lanjut mengenai hubungan asupan gizi makro dan asupan gizi mikro dengan 
stunting anak usia 24-59 bulan di wilayah kerja Puskesmas Kabere Kecamatan Cendana Kabupaten Enrekang.

\section{BAHAN DAN METODE}

Tujuan dari penelitian ini adalah untuk mengetahui hubungan asupan zat gizi makro dan zat gizi mikro dengan stunting pada anak usia 24-59 bulan di wilayah kerja Puskesmas Kabere Kabupaten Enrekang. Sampel pada penelitian ini yaitu anak usia 24-59 bulan yang memenuhi syarat inklusi dan eksklusi. Adapun syarat inklusi yaitu orang tua atau pengasuh anak balita usia 24-59 bulan yang stunting berdasarkan tinggi badan menurut umur yang berada di wilayah kerja puskesmas Kabere, serta bersedia berpartisipasi dalam penelitan. Sedangkan syarat untuk kriteria eksklusi meliputi responden tidak berada di tempat sewaktu penelitian dan memiliki kelainan dalam hal ini memiliki cacat bawaan lahir.

Jenis penelitian yang digunakan adalah deskriptif analitik dengan rancangan cross sectional. Sampel penelitian ini adalah balita usia 24-59 bulan. Didapatkan sebanyak 105 sampel. Teknik sampling dalam penelitian ini adalah cara probability sampling menggunakan teknik purposive sampling. Tinggi badan sampel di ukur menggunakan microtoice dengan ketinggian) $1 \mathrm{~cm}$ dan di perhitungan status gizi dilakukan menggunakan alikasi WHO Anthro. Asupan zat gizi makro dan mikro di ukur dengan cara wawancara langsung kepada orang tua, dengan menggunakan recall 24 jam) selama dua hari yang dilakukan pada hari kerja dan akhir pekan. setelah itu data di dianalisis menggunakan aplikasi nutrisurvey kemudian dibandingkan dengan AKG. Setelah itu, data dianalisis menggunakan SPSS dan Microsoft Excel dengan menggunakan Uji Chi-Squere.

\section{HASIL}

Hasil penelitian untuk distribusi karakteristik responden menunjukkan bahwa dari 105 sampel, 55 (52.4\%) berjenis kelamin laki-laki, dan 50 (47.6\%) berjenis kelamin perempuan. Berdasarkan umur sampel yang terbanyak adalah umur 24-35 bulan 45 balita (42.9\%), dan yang paling sedikit adalah umur 48-59 bulan 19 balita (18.1\%). Berdasarkan asupan karbohidrat, asupan karbohidrat kurang sebanyak 51 balita $(48.6 \%)$ dan asupan karbohidrat cukup 54 balita (51.4\%). Asupan protein kurang sebanyak 50 balita (47.6\%) dan asupan protein cukup sebanyak 55 balita (53.4\%), serta asupan lemak kurang sebanyak 50 balita (47.6\%) dan asupan lemak cukup sebanyak 55 balita (52.4\%). Untuk asupan zat gizi mikro, asupan zat besi kurang sebanyak 70 balita (66.7\%) dan asupan zat besi cukup 35 balita (33.3\%), asupan zink kurang sebanyak 81 balita (77.1\%) dan asupan zink cukup sebanyak 24.1 balita (22.9\%), untuk asupan kalsium kurang sebanyak 73 balita (69.5\%) dan asupan kalsium cukup sebanyak 32 balita (30.5\%), serta asupan vitamin D kurang sebanyak 95 balita (90.5\%) dan asupan vitamin D cukup sebanyak 10 balita (9.5\%) (tabel.1). hasil penelitian jga menunujukkan bahwa jumlah sampel balita stunting sebesar $46.7 \%$ dan jumlah balita normal sebesar $53.3 \%$. 
Tabel 1. Distribusi Frekuensi Karakteristik Sampel di Wilayah Kerja Puskesmas Kabere Kecamatan Cendana Kabupaten Enrekang Tahun 2019

\begin{tabular}{ccc}
\hline Kategori & N & \% \\
\hline Jenis Kelamin & & 52,4 \\
Laki-laki & 55 & 47.6 \\
Perempuan & 50 & \\
\hline Umur & & 42,9 \\
24-35 Bulan & 45 & 39,0 \\
36-47 Bulan & 41 & 18,1 \\
48-59 Bulan & 19 & 100 \\
\hline Total & 105 &
\end{tabular}

Sumber: Data Primer, 2019

Hasil analisis hubungan antara asupan karbohidrat dengan stunting pada balita diperoleh bahwa asupan karbohidrat kurang sebagian besar mempengaruhi stunting yaitu sebesar $60 \%$.

Tabel 2. Hubungan Antara Zat Gizi Makro dengan Stunting pada Anak Usia 24-49 Bulan di Wilayah Kerja Puskesmas Kabere Kecamatan Cendana Kabupaten Enrekang Tahun 2019

\begin{tabular}{|c|c|c|c|c|c|c|c|}
\hline \multirow{3}{*}{ Zat Gizi Makro } & \multicolumn{4}{|c|}{ Status Gizi } & \multicolumn{2}{|c|}{ Total } & \multirow{3}{*}{$p$-value* } \\
\hline & \multicolumn{2}{|c|}{ Stunting } & \multicolumn{2}{|c|}{ Tidak Stunting } & \multirow{2}{*}{$\mathbf{n}$} & \multirow{2}{*}{$\%$} & \\
\hline & $\mathbf{N}$ & $\%$ & $\mathbf{N}$ & $\%$ & & & \\
\hline \multicolumn{8}{|l|}{ Karbohidrat } \\
\hline Cukup & 18 & 33,3 & 36 & 66,7 & 54 & 100 & 0.005 \\
\hline Kurang & 31 & 60,8 & 20 & 39,2 & 51 & 100 & \\
\hline \multicolumn{8}{|l|}{ Protein } \\
\hline Cukup & 7 & 12,7 & 48 & 16,0 & 55 & 100 & 0.000 \\
\hline Kurang & 42 & 84,0 & 8 & 87,0 & 50 & 100 & \\
\hline \multicolumn{8}{|l|}{ Lemak } \\
\hline Cukup & 18 & 30,0 & 44 & 80,0 & 56 & 100 & 0.000 \\
\hline Kurang & 38 & 78,0 & 12 & 24,0 & 49 & 100 & \\
\hline
\end{tabular}

Sumber: Data Primer 2019

Hasil uji statistik di dapatkan p-value 0.005, artinya ada hubungan yang signifikan antara asupan karbohidrat dengan stunting, dari hasil analisis terdpat bahwa ada hubungan antara asupan protein dengan stunting pada balita diperoleh bahwa sebagian besar asupan protein kurang pada balita sebesar $84 \%$ dengan hasil uji statistik di dapatkan $p=$ value 0.000 yang berarti ada hubungan yang signifikan antara hubungan antara asupan protein dengan stunting. Hubungan asupan lemak dengan stunting menunjukkan hasil ada hubungan antara asupan lemak dengan stunting pada balita diperoleh bahwa asupan lemak kurang pada balita stunting sebesar $84 \%$ dengan hasil uji statistik $p$-value 0.000 yang berarti ada hubungan yang 
signifikan antara asupan lemak dengan stunting.

Hasil analisis hubungan asupan zat besi dengan stunting pada balita diperoleh bahwa pada balita stunting asupan zat besi kurang sebesar 67\%, dengan hasil uji statistik di dapatkan p-value 0.000 yang berarti ada hubungan yang signifikan antara asupan zat besi dengan stunting, dari hasil analisis terdapat hubungan yang signifikan antara asupan zink dengan stunting pada balita diperoleh bahwa sebagian besar asupan zink kurang pada balita sebesar $79.2 \%$, dengan hasil uji statistik p-value 0.004 yang berarti ada hubungan signifikan antara asupan zink dengan stunting.Berdasarkan hasil uji statstik hubungan asupan kalsium dengan stunting diperoleh p-value 0.213 yang berarti tidak ada hubungan yang signifikan antara hubungan asupan kalsium dengan stunting (tabel.8). Pada balita stunting asupan kalsium kurang sebesar 50.7\%. hubungan asupan vitamin D dengan stunting menunjukkan hasil tidak ada hubungan yang signifikan antara asupan vitamin D dengan stunting. Hasil uji statistik di dapatkan p-value 0.267 yang berarti tidak ada hubungan yang signifikan antara asupan vitamin D dengan stunting.

Tabel 3. Hubungan Antara Zat Gizi Mikro dengan Stunting pada Anak Usia 24-49 Bulan di Wilayah Kerja Puskesmas Kabere Kecamatan Cendana Kabupaten Enrekang Tahun 2019

\begin{tabular}{|c|c|c|c|c|c|c|c|}
\hline \multirow{3}{*}{ Zat Gizi Mikro } & \multicolumn{4}{|c|}{ Status Gizi } & \multicolumn{2}{|c|}{ Total } & \multirow{3}{*}{ p-value* } \\
\hline & \multicolumn{2}{|c|}{ Stunting } & \multicolumn{2}{|c|}{ Tidak Stunting } & \multirow{2}{*}{$\mathbf{n}$} & \multirow{2}{*}{$\%$} & \\
\hline & $\mathbf{N}$ & $\%$ & $\mathbf{N}$ & $\%$ & & & \\
\hline \multicolumn{8}{|l|}{ Zat Besi } \\
\hline Cukup & 3 & 8.6 & 32 & 91.4 & 35 & 100 & 0.000 \\
\hline Kurang & 46 & 65.7 & 24 & 34.3 & 70 & 100 & \\
\hline \multicolumn{8}{|l|}{ Zink } \\
\hline Cukup & 5 & 20.8 & 19 & 79.2 & 24 & 100 & 0.004 \\
\hline Kurang & 44 & 54.3 & 37 & 45.7 & 81 & 100 & \\
\hline \multicolumn{8}{|l|}{ Kalsium } \\
\hline Cukup & 12 & 37.5 & 20 & 62.5 & 32 & 100 & 0.213 \\
\hline Kurang & 30 & 50.7 & 36 & 49.3 & 73 & 100 & \\
\hline \multicolumn{8}{|l|}{ Vitamin D } \\
\hline Cukup & 3 & 30 & 7 & 70 & 56 & 100 & 0.267 \\
\hline Kurang & 46 & 48.4 & 49 & 51.6 & 49 & 100 & \\
\hline
\end{tabular}

Sumber: Data Primer 2019

\section{PEMBAHASAN}

Jenis Kelamin merupakan salah satu faktor yang menentukan besar kecilnya kebutuhan gizi seseorang. Namun, jenis kelamin pada balita tidak ada pengklarifikasian karena baik jenis kelamin perempuan maupun laki-laki mempunyai kebutuhan yang sama yaitu sama-sama masuk dalam masa pertumbuhan terlihat berdasarkan AKG pada balita. ${ }^{5}$ Pada usia balita merupakan masa kritis pada masa pertumbuhan atau disebut sebagai periode emas (golden period). Pertumbuhan dan perkembangan anak di masa ini menjadi penentu keberhasilan pertumbuhan dan perkembangan anak di periode selanjutnya. ${ }^{6}$ Masa tumbuh 
kembang di usia ini merupakan masa yang berlangsung cepat dan tidak akan pernah terulang. ${ }^{5}$

Stunting (kerdil) merupakan kondisi dimana balita memiliki panjang atau tinggi badan yang kurang jika dibandingkan dengan umur. ${ }^{7}$ Keadaan pendek adalah indikator ksehatan anak yang menggambarkan kejadian gizi kurang yang berlangsung dalam waktu yang lama (kronis). ${ }^{8}$ Stunting tidak hanya menjadi terjadi di Kecamatan Cendana saja, tetapi stunting juga menjadi masalah kesehatan masyarakat utama hampir di semua provinsi di Indonesia. ${ }^{3}$ Penelitian yang dilakukan oleh Widyaningsih (2018) menunjukkan bahwa persentase anak usia 24-59 yang mengalami stunting di wilayah Kecamatan Bayat, Kabupaten Klaten sebesar $41 \%{ }^{9}$

Berdasarkan hasil uji statik terdapat hubungan asupan karbohidrat dengan stunting pada balita 24-59 bulan diperoleh nilai $p=0.005$. Penelitian ini sejalan yang dilakukan oleh Ayungningtyas (2018) yang menunjukkan bawha ada hubungan yang signifikan $(p=0.003)$ antara asupan karbohidrat dengan stunting pada balita 24-59 bulan di wilayah kerja Puskesmas Sumber Urip Kabupaten Rejang. Hasil diperoleh bahwa asupan karbohidrat kurang sebesar $54.4 \%$ dan asupan karbohisrat cukup pada balita stunting sebesar $13.9 \%{ }^{10}$ Berdasarkan uji statistik terdapat hubungan asupan protein dengan stunting pada balita 24-59 bulan diperoleh nilai $p=0.000$. Penelitian ini sejalan dengan Haya (2016) menunjukkan bahwa anak dengan status gizi yang normal sebesar $65 \%$ dengan asupan protein yang cukup, sedangkan anak yang mengalami stunting sebesar $83.1 \%$ dengan asupan protein yang kurang. Balita yang tingkat kecukupan proteinnya kurang memiliki kemungkinan menjadi stunting sebesar 7,65 kali dibandingkan dengan balita yang tingkat kecukupan proteinnya baik. ${ }^{11}$

Berdasrkan uji statistik terdapat hubungan asupan lemak dengan stunting pada balita diperoleh nilai $p=0.000$. Penelitian ini juga sejalan dengan penelitian Oktarina (2014) yang menunjukkan bahwa balita dengan tingkat asupan lemak yang rendah mengalami stunting lebih banyak di bandingkan balita dengan supan lemak yang cukup, hasil penelitian menunjukkan terdapat hubungan asupan lemak dengan kejadian stunting. Balita dengan tingkat asupan lemak rendah berisiko mengalami stunting dibandingkan dengan tingkat asupan lemak yang cukup. ${ }^{12}$

Berdasarkan hasil uji statistik terdapat hubungan asupan zat besi dengan stunting pada balita dengan nilai $p=0.000$. Penelitian ini sejalan dengan penelitian yang dilakukan di Desa Suci, Kecamatan Manyar, Kabupaten Gresik. Balita yang memiliki tingkat kecukupan zat besi yang inadekuat dan mengalami stunting sebanyak 33\%. Hasil uji Chi-square diperoleh nilai $\mathrm{p}=0.001$ yang berarti ada hubungan yang signifikan antara asupan zat besi dengan stunting pada balita. ${ }^{13}$

Berdasarkan hasil uji statistik terdapat hubungan antara asupan zink dengan stunting dengan nilai $p=0.004$. Penelitian ini sejalan dengan Astutik (2018) yang menunjukkan bahwa ada hubungan antara asupan zik dengan kejadian stunting pada balita. Asupan zink balita yang kurang memiliki 4.241 kali untuk mengalami kejadian stunting di bandingkan dengan asupan zink yang cukup pada balita. ${ }^{14}$

Berdasarkan uji statistik tidak terdapat hubungan kalsium dengan stunting dengan nilai $p=0.213$. Penelitian ini sejalan dengan penelitian yang dilakukan di Kecamatan Semarang Timur yang menunjukkan bahwa tidak ada hubungan yang signifikan antara asupan kalsium dengan kejadian stunting. Asupan kalsium kurang terdapat lebih banyak jumlahnya pada anak yang berstatus gizi pendek di bandingkan dengan anak yang berstatus gizi normal. ${ }^{7}$ 
Berdasarkan uji statistik tidak terdapat hubungan asupan vitamin D dengan stunting dengan nilai $p=0.267$. Penelitian ini sejalan dengan penelitian yang dilakukan di wilayah kerja Puskesmas Urip Kabupaten Rejang, yang menyebutkan bahwa tidak ada hubungan yang signifikan antara asupan Vitamin D dengan stunting $(p=0,811)$. Tidak adanya hubungan pada penelitian yang dilakukan dikarenakan sumber vitamin $\mathrm{D}$ hanya didapatkan dari segi makanan saja sedangkan sumber vitamin D juga terdapat dari paparan sinar matahari pagi. Dalam penelitan ini tidak diukur secara detail berapa lama pemaparan sinar matahari yang di dapatkan balita. ${ }^{10}$

\section{KESIMPULAN}

Kesimpulan dari penelitian ini adalah Terdapat 56 anak balita dengan status gizi normal, dan 49 balita yang mengalami stunting pada anak usia 24-59 bulan. Terdapat hubungan yang signifikan antara asupan karbohidrat, protein, lemak, zat besi dan zink dengan stunting pada anak usia 24-59 bulan. Sedangkan asupan kalsium dan vitamin D tidak berhubungan signifikan dengan stunting pada anak usia 24-59 bulan.

\section{DAFTAR PUSTAKA}

1. Saputra W, Nurrizka RH. Faktor Demografi dan Risiko Gizi Buruk dan Gizi Kurang. Makara Kesehatan. 2012;16(2):95-101.

2. Fitri L. Stunting di Puskesmas Lima Puluh Pekanbaru. 2018;3(1):131-7.

3. Kementrian Kesehatan RI. Hasil Utama Riskesdas 2018. 2018;61.

4. Black RE, Victora CG, Walker SP, Bhutta ZA, Christian P, Onis M De, et al. Maternal and Child Nutrition 1 Maternal and Child Undernutrition and Overweight in Low-Income and Middle-Income Countries. 2014;

5. Darmawati M. Ilmu Gizi Teori dan Aplikasi. Jakarta: Buku Kedokteran EGC; 2014.

6. Almatsir. Prinsip Dasar Ilmu Gizi. Jakarta: PT.Gramedia Pustaka Utama; 2004.

7. Anshori H A. Faktor Risiko Kejadian Stunting Pada Anak 12-24 Bulan (Studi Kecamatan Semarang Timur). 2013;(1):23-7.

8. Paudel R, Pradhan B, Wagle R, Pahari D, Onta S. Risk Factors for Stunting Among Children: A Community Based Case Control Study in Nepal. Kathmandu Univ Med J. 2013;10(3).

9. Widyaningsih NN, Kusnandar K, Anantanyu S. Keragaman pangan, pola asuh makan dan kejadian stunting pada balita usia 24-59 bulan. J Gizi Indones. 2018;7(1):22.

10. Ayuningtyas, Simbolon D, Rizal A. Asupan Zat Gizi Makro dan Mikro terhadap Kejadian Stunting pada Balita. J Kesehat. 2018;9(November):444-9.

11. Haya M, E. MS, Margawati A. Jurnal Gizi Indonesia: The Indonesian Journal of Nutrition. J Gizi Indones [Internet]. 2016;4(1):9-15. Available from: https://www.neliti.com/id/publications/80436/pengaruh-pendidikan-kesehatan-bagi-ibuterhadap-asupan-energi-aktivitas-fisik-da

12. Oktarina Z, Sudiarti T. Faktor Risiko Stunting Pada Balita ( $24-59$ Bulan ) di Sumatra. 2014;(May).

13. Dewi EK, Nindya TS. Hubungan Tingkat Kecukupan Zat Besi dan Zink dengan Kejadian Stunting Pada balita 6-23 Bulan. 2017;261-368. 
14. Astutik, Rahfiludin MZ, Aruben R. Faktor Risiko Kejadian Stunting Pada Anak Balita Usia 24-59 Bulan (Studi Kasus di Wilayah Kerja Puskesmas Gabus II Kabupaten Pati. J Kesehat Masyaraka. 2018;6:409-8. 